\title{
KONCEPT BEZBEDNOSTI
}

\author{
Mladen S. Kostić \\ Generalštab Vojske Srbije, Uprava za planiranje i razvoj (J-5)
} figurirala. Nijedan društveni pojam ili koncept nije bio toliko zloupotrebljavan i pogrešno korišćen kao nacionalna bezbednost. Svrha ovog rada je pokušaj objašnjavanja koncepta bezbednosti u širem kontekstu, kako bi bio primenljiv na više nivoa, ali sa posebnim osvrtom na nacionalnu bezbednost. Nastojano je da se definiše bezbednost kao politički cilj, dovoljno jasan da se razlikuje od drugih ciljeva. Da bi se izvršilo bliže pojmovno određenje potrebno je identifikovati određene „specifikacije” ili „određenja” bezbednosti, koje mogu da olakšaju analizu svrsishodnosti bezbednosne politike. Ako će ovaj pojam opstati za upotrebu u političkim analizama ili teorijama biće neophodna konceptualna određenja (specifikacije), a za početak može se odrediti bezbednost kao cilj politike i pristupiti daljem određenju politike kao sredstva za dostizanje tog cilja.

Ključne reči: koncept bezbednosti, nacionalna bezbednost, konceptualna analiza, specifikacije ili određenja bezbednosti

\section{Uvod}

U razmatranju pojma bezbednosti u savremenoj nauci ne postoji jedinstveni pristup ovom problemu. U savremenoj nauci neprestano egzistira nekoliko različitih pravaca sa mnoštvom različitih definicija i jezičkih kombinacija. Bezbednost je opšti pojam, koji je u srpskom jeziku izveden od reči „bez” i „beda”, što u prevodu znači: „bez nevolje”. U naj-opštijem smislu ovaj pojam podrazumeva odsustvo nevolje, bez obzira na to da li je ona prouzrokovana ratom, nasiljem, siromaštvom, prirodnim nepogodama, kao što su poplave, požari, zemljotresi, kataklizme, bolesti ljudi i životinja, pa sve do najnovijih nevolja savremenog čoveka, kao što su nezaposlenost, narkomanija, kriminal, trgovina ljudima, proliferacija naoružanja, ekološke katastrofe itd. Koncept bezbednosti predstavlja jednu od najznačajnijih oblasti za istraživače društvenih pojava i nalazi se u središtu interesovanja nauke o međunarodnim odnosima, kao i drugih nauka. Nekoliko decenija i na Zapadu i na Istoku traje razvoj proučavanja bezbednosti u znatno širim okvirima, koja često zahvataju gotovo sve oblasti društvenih i delom prirodnih nauka, sa utemeljenjem u klasičnoi filozofiii. Savremeni trendovi alobalizaciie i nametania zapadne kulture impliciraju izmenu pristupa u razmatranju sadržaja pojma bezbednosti.

\footnotetext{
*mladen.kostic@upir.vs

${ }^{1}$ Слободан Нешковић, Безбедност и реформе у Србији, Прометеј, Београд, 2006. год., стр. 11-17.
} 
Većina napora koji se čine na polju redefinisanja pojma bezbednosti usmereno je na ono što se odnosi na državu, a ne na koncept bezbednosti sam po sebi. Često se novi predlozi u vezi sa ovim pojmom odnose na pitanja ljudskih prava, ekonomiju, okolinu, trgovinu narkoticima, epidemije, kriminal ili socijalne nepravde, što predstavlja novinu u odnosu na tradicionalnu pažnju prema bezbednosti od vojnih pretnji. Ovi stavovi obično su potkrepljeni različitim normativnim činjenicama o tome koje vrednosti određenih ljudi ili društvenih grupa treba štititi i empirijskim dokazima o prirodi i intenzitetu pretnji tim vrednostima. Zapravo, malo je pažnje posvećeno samom značenju koncepta „bezbednost” kao takvom. Skrivanje normativnih i empirijskih debata u puko teoretisanje i razmatranje naglašava konceptualne razlike između zastupnika različitih bezbednosnih politika i ometa naučnu komunikaciju i razumevanje. S obzirom na takve, naizgled nepomirljive razlike, potrebno je odrediti zajedničke konceptualne odlike, koje se nalaze u različitim konceptima.

Zanemarivanje bezbednosti kao koncept prisutno je i odražava se u pitanjima bezbednosti u nekim akademskim krugovima. Knor je jedan svoj rad počeo sa namernim zaobilaženjem semantičkih i problema definisanja termina „nacionalna bezbednost”. Smok R. je primetio da se na ovom polju ne obraća dovoljno pažnje na oblast značenja „bezbednost”. 3 Bazan opisuje bezbednost kao nerazvijeni koncept i primećuje nedostatak konceptualne literature pre osamdesetih. ${ }^{4}$ lako uočava napredak na ovom polju u toku osamdesetih i dalje postoji trend zanemarivanja.

\section{Pojmovno određenje bezbednosti}

Uzimajući u obzir mnogobrojne pokušaje da se redefiniše pojam bezbednosti, nakon završetka hladnog rata, mnogi se pitaju da li je zaista ovaj pojam zanemarivan. Postoje dva razloga za ovakvu tvrdnju. Prvi je sam značaj pojma, koji je mnogo puta upotrebljen kao opravdanje za ukidanje građanskih sloboda, izbijanje ratova i veliko trošenje resursa u poslednjih šezdeset godina, a uprkos mnogobrojnim radovima na tu temu nije dovoljno rasvetljen. Drugi je taj što gotovo svi ti radovi nisu uzeli u obzir razmatranje prema načinu i kriterijumima, prethodno opisanim u konceptualnoj analizi prema Openhajmu. $\mathrm{Na}$ značenje pojma bezbednosti još uvek nije obraćena dovoljna pažnja iz ugla pravosuđa, slobode, jednakosti, obaveza, predstavljanja i moći. ${ }^{5}$

Bazan objašnjava da postoji pet razloga za zanemarivanje ovog pojma. Prvi je složenost pojma, iako priznaje da ovaj pojam nije ništa složeniji od drugih. Drugi razlog je preklapanje pojma bezbednosti sa pojmom moći, što bi, s obzirom na lako uočljive međusobne razlike, trebalo da utiče na teoretičare da se pozabave razjašnjavanjem oba pojma. Treći je nedostatak interesovanja kritičara realističkih teorija u politici, četvrti je veće zanimanje teoretičara za razvoj tehnologije i politike, a peti, što je vrlo zanimljivo, očigledno

\footnotetext{
${ }^{2}$ Klaus Knorr, 'National Security Studies: Scope and Structure of the Field', in Frank N. Trager and PhilipS. Kronenberg (eds.), National Security and American Society: Theory, Process and Policy (Lawrence, KS, 1973), str. 5

${ }^{3}$ Richard Smoke, 'National Security Affairs', in Fred I. Greenstein and Nelson W Polsby (eds.), Handbook of Political Science, Vol. 8: International Politics (Reading, MA, 1975), str. 259.

${ }^{4}$ Buzan, People, States, str. 3-4.

${ }^{5}$ Peter Digeser, 'The Concept of Security', paper delivered at the 1994 Annual Meeting of the American Political Science Association, 14 September 1994.
} 
namerno zanemarivanje pojma nacionalne bezbednosti, od strane političara, jer su otkrili da je to veoma korisno, što opet ne opravdava teoretičare. To je paradoksalno.

Većina teoretičara je pri razmatranju pitanja bezbednosti podrazumevala primenu vojne sile i njenu povezanost, odnosno uticaj na bezbednost, ali nacionalnu. Pitanja koja nisu bila vezana za vojnu silu smatrana su relevantnim za nižu ili dnevnu politiku. Tako Bazan naglašava da je predmet izučavanja nauka o bezbednosti bio vojska, odnosno oružane snage.

Zapravo, veliki broj autora je pokušavao da definiše i odredi sadržaj pojma bezbednosti, kao nacionalne bezbednosti, pa će neki pogledi biti prezentovani kako bi se stekao uvid u kompleksnost problema.

Pol Kenedi ističe da je pojam nacionalne bezbednosti u klasičnom smislu vojne pretnje izmenjen i naglašava značaj ekonomije tako da „svežije pretnje bezbednosti (demografski i ekološki problemi) postaje u jednom većem i integrisanijem smislu sve više neodvojiva od međunarodne bezbednosti. Pretnje nacionalnoj bezbednosti znače bilo šta na planeti što ugrožava ljudsko zdravlje, ekonomsko blagostanje, socijalnu stabilnost i politički mir".

Sajdel i Levi navode da „nacionalna bezbednost znači bezbednost zasnovanu na vojnim merama, defanzivnim kapacitetima, čak i kada očigledni imaju sposobnost ofanzivne upotrebe. Ove mere obično uključuju ubeđivanje mogućih neprijatelja i saveza u spremnost da koriste vojne mere - da ratuju, zbog zaštite nacionalne bezbednosti i često za rezultat imaju trku u naoružanju". ${ }^{7}$

Havedi definiše nacionalnu bezbednost kao „delatnost nacionalnih država kojom one, u skladu sa svojim društvenim mogućnostima i sadašnjosti i budućnosti, uzimajući u obzir globalne promene i razvoj, štite vlastiti identitet, opstanak i interese". 8 tim u vezi, država preduzima najrazličitije aktivnosti iz raznih oblasti (privreda, nauka, kultura) kako bi se zaštitila od spoljnih uticaja i izazova.

Bazan pod užim pojmom nacionalne bezbednosti podrazumeva isključivo spoljnu bezbednost države i tradicionalnu politiku odbrane povezane sa tradicionalnim shvatanjem nacionalnog interesa. „Nacionalna bezbednost podrazumeva spsobnost da se odupre spoljnoj agresiji”. ${ }^{9}$ Pod širim pojmom „nacionalna bezbednost podrazumeva očuvanje ugodnog živoat ljudi podudarnog sa potrebama i legalnim namerama drugih. Ona uključuje slobodu od oružanih napada i pritisaka, slobodu od unutrašnjih subverziteta i slobodu od erozije političkih, ekonomskih i socijalnih vrednosti koje predstavljaju suštinu kvaliteta života". ${ }^{10}$

Grizold ističe da „nacionalna bezbednost podrazumeva sigurnost političkog naroda, čiji sadržaj obuhvata: sigurnost nacionalnog teritorija (uključujući zračni prostor i teritorijalne vode), zaštitu života ljudi i njihova vlasništva, očuvanje i održavanje nacionalne suverenosti i ostvarivanje osnovnih funkcija društva (socijalno-ekonomske, društvenopolitičke, kulturne, ekološke, gospodarske i dr.)".

Miletić smatra da sadržaj nacionalne bezbednosti obuhvata: „a) odsustvo ili bar takvu prirodu u nivo pretnje na opstanak i nezavisnost nacije-države, koji omogućuju b) da se sop-

\footnotetext{
${ }^{6}$ Кенеди П., Припрема за ХХИ век, Службени лист, Београд, 1997. год, стр. 148-151.

${ }^{7}$ Sidel V. Levy B., Security and Public health.in, Social Justice Vol 29, str. 108-119.

${ }^{8}$ Hewedy A., Militarisation and Security in the Middle East, Pinter Publishers, London, str.14.

${ }^{9}$ Buzan B., People State and Fear: An Agenda for International Security Studies/ In the Post Cold War Era, Pearson Longman, London, 1991. god., str. 16-17.

${ }^{10}$ isto.

${ }^{11}$ Griyol A., Realities of American Foreign Policy, Njujork, 1960. god., str. 77.
} 
stvenim, eventualno savezničkim i drugim sredstvima (kolektivne bezbednosti, npr.) one otklone i s tim u vezi, c) odsustvo straha, odnosno. osećanje spokojstva". ${ }^{12}$ Autor pod referentnim objektima nacionalne bezbednosti podrazumeva, pored države i njenog suvereniteta, odnosno teritorijalnog integriteta i pojedince, društvene grupe i društvo. Naime, odsustvo straha i osećanje spokojstva, kako navodi, obuhvata: politički mir, ljudsko zdravlje, socijalnu stabilnost i ekonomsko blagostanje. Stavljanjem nacionalne bezbednosti u zavisan odnos prema sistemu kolektivne bezbednosti ukazuje na to da potreba za dostizanjem, očuvanjem i unapređenjem nacionalne bezbednosti nije samo u odbrambenim potencijalima države, već u sposobnosti da vlastitu bezbednost sudbinski veže za međunarodnu bezbednost. ${ }^{13}$

Ekspert za međunarodno pravo i publicista dr Avramov ističe da su se: „Paradigme i institucionalni modeli bezbednosti menjali tokom razvoja međunarodne zajednice “ i „iako odbrana od spoljnjeg napada ostaje centralni problem, praksa je nedvosmislemo ukazivala da država može biti ugrožena unutrašnjim potresima, ekonomskom i drugim poremećajima, naročito u zajednicama u kojima nedostaje osećaj identiteta i socijalne kohezije". To je razlog diferenciranja pojma nacionalne bezbednosti i bezbednosti društva i dalje se ističe: „osnovni kriterijum bezbednosti države predstavlja njen suverenitet, a bezbednosti društva identitet, odnosno, svest o pripadnosti zajednici. Kroz oba termina prožima se u biti egzistencija ili preživljavanje države i društva; država koja izgubi suverenitet prestaje da bude država, a kada društvo izgubi identitet prestaje da postoji kao suverena jedinka. Razdvajanje državne i društvene bezbednosti treba shvatiti u smislu dva organizaciona centra bezbednosti, ali u središtu bezbednosne dileme ostaje i dalje država, bilo da je reč o socijalnom vidu bezbednosti ili međunarodnom. Država je ta koja pruža legitimitet i zaštitu društva. Drugi nivo pristupa bezbednosti je podela na nadnacionalnu i međunarodnu, ali se i u ovom slučaju država javlja kao ključna karika”. ${ }^{14}$

Može se uočiti da je klasičan koncept nacionalne bezbednosti zadržao bitno mesto u pojmu bezbednosti, ali da je prisutan opšti trend proširenja sadržaja konceptima kao što su: pojedinačna, društvena i globalna bezbednost, a što opet upućuje na veći broj referentnih objekata bezbednosti, kao što su pojedinci, društvene grupe, države, međunarodne organizacije i multinacionalne kompanije i međunarodni sistem.

Mnogi teoretičari su pitanje bezbednosti smatrali spornim konceptom. To je bitno pomenuti zbog određenja šta je sporno u nekom određenju, da li je uopšte sporno i ako jeste da li je to relevantno i za studije bezbednosti.

Suštinski sporni koncepti nemaju dovoljno dokaza koji mogu dovesti do jedne teorije ili varijante, kao „korektne” il „opšte upotrebljive”. To vodi u radikalan skeptički nihilizam u kojem nema dovoljno razloga da se jedan koncept preferira u odnosu na drugi, što konceptualnu analizu čini uzaludnom. Ima nešto blažih zastupnika ovog stava koji dozvoljavaju mogućnost da može postojati razlika između bolje i gore konceptualizacije, ali se ni za jednu ne može reći da je najbolja.

Ipak, nije najjasnije kako je bezbednost sporan pojam, kada su bar dva od više zahteva za takvo određenje vrlo upitna. Kao prvo, koncept mora biti procenljiv u smislu da se može odrediti vrednost nekog dostignuća. Gali koristi primer „šampiona” u sportu, koji označava najbolji tim.

\footnotetext{
${ }^{12}$ Милетић А., Национални интерес у америчкој територији међународних односа, Савремена аминистрација, Београд, 1978.год., стр. 11.

${ }^{13}$ Слободан Нешковић, Безбедност и реформе у Србији, Прометеј, Београд, 2006. год. стр. 21-22.

${ }^{14}$ Аврамов С., Безбедност у 21. Веку, Зборник радова СИМБОН 2001., Београд, стр. 423.
} 
Za neorealiste pojam bezbednosti je sličan ovom određenju, jer je bezbednost najvažniji cilj u međunarodnim odnosima. Ako je država „šampion” onda je bezbedna. ${ }^{15}$

Volfer, ${ }^{16}$ međutim, ima drugi pogled na bezbednost i tvrdi da države mnogo variraju u odnosu na vrednost njihove pozicije u bezbednosti i da neke mogu biti toliko nezadovoljne stanjem „status quo” da požele više bezbednosti nego što je imaju. Iz ove perspektive, reći da jedna država ima više bezbednosti od druge je isto što i reći da je jedna država sa više stanovnika i većom površinom bolja od druge. Za Volfera međunarodna politika nije igra u kojoj sve države igraju prema istim pravilima i takmiče se za prvo mesto.

Svrha ovih razmatranja jeste da naglasi da je na ovo pitanje mnogo složenije dati odgovor nego klasifikovati bezbednost kao suštinski sporan koncept.

Drugi zahtev za određenje ovog koncepta, kao zaista potpuno neodređenog, jeste određivanje karakteristika takvog koncepta, takvo da mora stvarati snažno neslaganje sa prirodom samog koncepta i njegovoj primeni u različitim slučajevima. Postoje velika neslaganja u stvarnom životu koja se odnose na suprotnosti između: interesa, ukusa ili stavova o nečemu. To upućuje na potrebu posebnog zastupanja i promišljanja svog stava nego na duboko filozofsko neslaganje. Zbog toga mnogi savremeni teoretičari u javnoj debati oko pretnji okolini, budžetskom deficitu, kriminalu ili trgovinom narkoticima kao pitanjima nacionalne bezbednosti ne predstavljaju takvo ozbiljno konceptualno neslaganje kao što to zahtevaju Galijevi standardi. Za Galija suštinsko osporavanje uzrokuje više od toga da različite strane upotrebljavaju različite verzije koncepta. Svaka strana mora da shvati suprotstavljenost (osporavanost) prirode koncepta koji upotrebljava i svaka mora da se upusti u ogorčenu debatu radi odbrane svog posebnog pojmovnog određenja. ${ }^{17}$ Ipak, to se ne dešava. Neorealisti jednostavno ignorišu Volferov pogled na bezbednost.

Ako je pitanje bezbednosti tako neodređeno onda čak i neke Buzanove implikacije postaju problematične. Ne može se pod izgovorom osporavanja koncepta zanemariti pokušaj vlastitog definisanja i formulacije. Ipak, on izričito obeshrabruje svaku nameru preciznog određenja, sugerišući da je takav poduhvat unapred osuđen na neuspeh zbog neshvatanja ovakvih pojmovnih određenja u društvenim naukama. ${ }^{18}$ Ovakav zaključak je potpuno neprihvatljiv, jer ako nešto ne možemo da imenujemo, kako ga možemo objasniti?

Dalje posledice ovakvih stavova je niz kontradiktornosti koje uključuju shvatanje individualne i državne bezbednosti, nacionalne i međunarodne, između nasilnih miroljubivih sredstava, između crnih i belih u Južnoafričkoj Republici, nacista i Jevreja u Drugom svetskom ratu itd. Ova neodređenost uključuje i hladni rat kao kontraktidornost između zemalja NATO-a i Varšavskog ugovora. Tačno je da država, tražeći bezbednost za sebe, može ući u sukob sa individualnom bezbednošću, ali je to više empirijska činjenica nego konceptualni problem. Većina pojava određenih Bazanovim konceptualnim (pojmovnom) osporavanjem (neodređenošću) može biti pogodnije nazvan područje konflikta empirijski proverljivog između različitih učesnika i politika. ${ }^{19}$

Može se zaključiti da, iako postoji određeno neslaganje, postoji i utemeljenje da je pojam bezbednosti pravilnije opisati kao konfuzan i nedovoljno objašnjen koncept nego kao sporan.

\footnotetext{
${ }^{15}$ Kenet Volc, Theory of International Politics (Reading, MA, 1979), and 'The Emerging Structure of International Politics', International Security, 18 (1993), str. 44-79.

${ }^{16}$ Arnold Wolfers, „National Security” as an Ambiguous Symbol', Political Science, Quarterly, 67, 1952.

${ }^{17}$ W B. Gallie, 'Essentially Contested Concepts', Proceedings of the Aristotelian Society, N.S., 56 (1956), str. 16.

${ }^{18}$ Buzan, People, States, and 'Peace, Power'; and Little, 'Ideology and Change'. For the original formulation, see W B. Gallie, 'Essentially Contested Concepts', Proceedings of the Aristotelian Society, N.S., 56 (1956), str. 98-167.

${ }^{19}$ David A. Baldwin, The concept of security, Review of International Studies (1997), 23, str. 12.
} 


\section{Koncepti bezbednosti}

Analizirajući učenja o nacionalnoj bezbednosti u XX veku i velikom delu hladnog rata koncept međunarodne bezbednosti određivan je vojnim pojmovima, a bezbednost se ticala nacionalne države i njene teritorije. Države su bile odgovorne za sopstvenu bezbednost, samostalno ili kroz savezništva sa drugim državama. Međutim, neprestanim promenama međunarodnog sistema ideja nacionalne bezbednosti se proširila i na druge dimenzije društva, tako da su, pored vojne, u nju sada uključene i politička, ekonomska, socijalna i ekološka dimenzija. Država, kao glavni subjekt međunarodne bezbednosti, gubi primat i pored nje na međunarodnoj sceni svoje mesto zauzimaju međunarodne organizacije, etničke grupe i pojedinci. Usled brojnih promena u međunarodnim odnosima može se izdvojiti nekoliko preovlađujućih pristupa bezbednosti, uopšteno svrstanih u tri grupe: realistički, liberalno-institucionalni i alternativno-kritički uz posebnu grupu globalističkog pogleda na bezbednost.

\section{Realistički pristup}

Grupu sa realističkim pristupom čine brojni pravci i podgrupe od tradicionalnih realista, neorealista, strukturalista i neostrukturalista do kontingentnih realista. Od vremena prvih poznatih odnosa političkih jedinica preko ustanovljavanja savremenog međunarodnog sistema država, bezbednost je određivana isključivo vojnim pojmovima, a od njenog nastanka glavni objekat i subjekat bezbednosti bila je suverena država. ${ }^{20}$

Morgentau je najznačajniji predstavnik klasične realističke škole, koji u centar pažnje, kao ključni elemenat ponašanja država u postojećem međunarodnom sistemu postavlja moć, tako da „ugaoni kamen političkog realizma, koji je teorijska osnova racionalne spoljne politike, je koncept nacionalnog interesa definisan kao moć". ${ }^{21}$

Država vlastitu bezbednost traži i nalazi u vlastitoj vojnoj moći i/li slabosti protivnika. Još određenije, od svih opasnosti koje prete osnovnim dobrima i usvojenim vrednostima države, kao ustanove u užem smislu i državi kao političkoj zajednici svih njenih građana, prevashodno se vodi računa o najstarijoj i najpoznatijoj - uspešnom oružanom napadu strane države, odnosno o ratu i porazu. ${ }^{22}$ Razmatrajući izložene tradicionalne postavke bezbednosti država je bezbedna samo kada ostvari ravnotežu između vojnih pretnji i vlastite vojne moći da na njih odgovori. Ponašanje država tokom cele istorije međunarodnih odnosa, zaključno sa hladnoratovskim razdobljem, svodi se na uvećanje vlastitih sposobnosti, a ne kroz smanjivanje pretnji kroz saradnju i zajedničko delovanje. Dovođenjem u vezu pojmova bezbednost i moć postavlja se pitanje merenja moći i, s tim u vezi, bezbednosti. Merenje moći je vrlo problematično i stvarni odnos se može videti tek u ratnom sukobu, što znači da ni najveća bezbednost ne može da počiva na gomilanju tradicionalnih vidova moći, jer takvi postupci uvek proizvode protivmere, bez obzira na to kako se pravda vlastito uvećanje moći.

\footnotetext{
${ }^{20}$ Симић Д., „Савремене теорије безбедности” у: Јанковић П., Реформа сектора безбедности - зборник предавања, Г17 институт, Београд, 2003. год., стр. 11-20.

${ }^{21}$ Симић Д., Наука о безбедности: савремени приступи безбедности, Службени лист СРЈ:ФПН, Београд, 2002. год., стр. 65.

${ }^{22}$ Димитријевић В., Појам безбедности у међународним односима, Савез удружења правника Југославије, Београд, 1973. год., стр. 40.
} 
Središnja zamisao najšireg realističkog pristupa jeste zamisao nacionalne bezbednosti, koja je ranije označavana kao spoljna bezbednost države. Dobro su poznate teškoće tačnog određivanja sadržaja ovog pojma, počev od toga da pojedini autori ne prave posebnu razliku između državne i nacionalne bezbednosti. Nikada se pouzdano ne zna, ukoliko se prethodno ne razjasni na koji se relevantni objekat misli: na državu kao ustanovu u užem smislu, na etnički određen i po pravilu većinski narod u njoj, na političku zajednicu svih državljana ili najpoželjnije, na sve građane, članove društva o kome je reč, nezavisno od njihove etničke, verske, socijalne i ideološke pripadnosti. ${ }^{23}$

Neorealistička struja u studijama bezbednosti, kao i doktrinarni realisti, smatra da je anarhičnost glavna odlika međunarodnog sistema. Takav sistem ne mora nužno da bude haotičan, ali postoji odsustvo centralnog ili središnjeg autoriteta, koji bi imao sposobnost da uređuje i presuđuje u odnosima između država. Međutim, države, u želji da uvećaju svoju moć, postaju međusobno opasne jedne prema drugima, bez obzira na to što im to i nije stvarna namera. Time se stvara neizvesnost, koja vodi nedostatku poverenja, što, opet, uzrokuje nepoznavanje krajnjih namera suseda, čime se zauzima sukobljen stav. Uz opštu tendenciju lažnog predstavljanja svoje sposobnosti postoji stalna opasnost da se napravi pogrešna procena stanja, koja u krajnjem vodi nepoverenju i agresivnom nastupu u međunarodnim odnosima. Suština problema nacionalne „nebezbednosti” je u strukturi međunarodnog sistema, zbog čega se pripadnici ove struje nazivaju još i strukturni realisti.

Predstavnici kontingentnog neorealističkog učenja o bezbednosti zastupaju stav da je u promenjenim međunarodnim okolnostima potrebnija veća saradnja među državama nego takmičenje u zadobijanju veće moći. Prihvatanjem ovakvih ideja države mogu izbeći opasnost i neizvesnost trke u naoružanju, što je pozitivan pravac u dostizanju, očuvanju i unapređenju sopstvene bezbednosti. Protivnici mogu ostvariti svoje ciljeve u postizanju nacionalne bezbednosti kroz saradnju, što prema Glaseru stvara uslove da „bezbednost postane zavisna od okoline koja preovlađuje u datom vremenskom periodu". ${ }^{24}$ Kontingentni realisti pokazuju pragmatičan optimizam u pogledu saradnje i uspostavljanja partnerstva na svetskoj političkoj sceni. Bazan sublimira stavove kontigentih realista da u postojećoj „zreloj anarhiji” ${ }^{25}$ postojećeg međuna-rodnog sistema države priznaju da postoje valjani razlozi da zbog vlastite nacionalne bezbednosti treba da uzmu „bezbedonosnu računicu” svojih suseda i šireg okruženja, odnosno da u novim okolnostima međunarodna bezbednost prethodi, predstavlja preduslov za dostizanje, očuvanje i unapređenje nacionalne bezbednosti. Država koja ne uvažava ovo stanje bezbednosne međuzavisnosti može da oseti kobne posledice u krajnjem ishodu. $^{26}$

\footnotetext{
${ }^{23}$ Симић Д., „Савремене теорије безбедности” у: Јанковић П., Реформа сектора безбедности - зборник предавања, Г17 институт, Београд, 2003. год., стр. 14-15.

${ }^{24}$ Glaser Ch., Realists as Optimists: Cooperation as Self/Help, International Security, Vol. 19, str. 50-90.

${ }^{25}$ Buzan B., People, States and Fear, second Edition, Harvester Wheatsheaf, London, 1991. god., str. 208.

${ }^{26}$ Nordijske zemlje su posle više vekova međusobnih borbi uspele da izgrade bezbednosnu zajednicu. Drugi slučaj je potpisivanje Rimskih protokola 1957. godine, kada su zemlje u zapadnoj Evropi prevladale i zamenile vekovna neprijateljstva, što je bio kamen temeljac za stvaranje Evropske unije (prim. aut.).
} 


\section{Liberalno-institucionalistički pristup}

Ovaj pravac razmišljanja nastavlja se na klasičan realistički pristup kroz shvatanje države kao osnovnog subjekta bezbednosti u anarhičnim međunarodnim odnosima koje odlikuje politika sile. Međutim, dok „realisti” strukturalnu anarhiju međunarodnog sistema vide kao neizbežnu i nepromenljivu posledicu oštrog razlikovanja između unutrašnje i spoljne politike, pri čemu je, po njima, u unutrašnjim odnosima moguće dostići pravdu, zajedništvo i društveni napredak, a ne i izvan države, liberalni institucionalisti ukazuju na značaj međunarodne saradnje, posebno one koja se ispoljava kroz njene multilateralne oblike i institucionalno udruživanje, kao najefikasnijeg načina za prevazilaženje nasilnih sukoba u odnosima naroda i država. Liberalni institucionalisti ističu prvenstveno političku, ekonomsku i kulturnu saradnju u odnosima „složene međuzavisnosti” bazirane na tekovinama izuzetnog tehničko-tehnološkog napretka i potiskuju fokusiranost relista na nacionalnu bezbednost, politiku sile i vojnu moć. To se najbolje može videti u konceptu Dojča koji je postavljen pedesetih godina XX veka: „Bezbedonosna zajednica je skup ljudi koji su se udružili. Pod udruživanjem ovde mislimo na dostizanje unutar jedne teritorije duha zajedništva i uspostavljanje snažnih i široko rasprostranjenih institucija i delatnosti dovoljnih da osiguraju pouzdanu miroljubivu saradnju između njenog stanovništva. Pod duhom zajedništva mislimo na verovanje ... da zajednički društveni problemi moraju i mogu biti razrešeni kroz procese miroljubive saradnje koja daje sigurnost da se članice neće međusobno fizički boriti, nego sukobe rešavati na neki drugi način". ${ }^{27}$

Usvajanje zajedničke bezbednosti kao organizujućeg načela u naporima da se umanji rizik od rata, ograniči naoružavanje i krene ka razoružavanju, znači, u principu, da će saradnja zameniti konfrontaciju u rešavanju sukoba interesa. To ne znači očekivanje da razlike između naroda treba da nestanu. Suština je u tome da takvi sukobi ne dovedu do rata ili priprema za rat. Zanimljivo je istaći i skup shvatanja zagovornika „teorija demokratskog mira”, po kojem demokratske države ne ratuju između sebe. Sledeći stavove Kanta, iznetim u njegovom ogledu „O večitom miru” iz 1795. godine Dojl i Raset smatraju da društva koja su institucionalno, pravno i proceduralno ostvarila istinsko demokratsko predstavljanje, ispoljavaju privrženost poštovanju ljudskih prava i pritom su sklonija miru od drugih društava. ${ }^{28} U$ okviru liberalnog institucionalizma, kolektivna bezbednost, kao ustanova međunarodne bezbednosti, teorijski je, ali i u stvarnosti, najprisutniji model. „Kolektivna bezbednost se odnosi na: zajedničko obezbeđivanje, bez unapred određenog protivnika, usmereno unutra i zasnovano na obavezi priticanja u pomoć onom subjektu koji je žrtva agresije, bez obzira na to koji drugi pripadnik nasrće na njegovu nacionalnu bezbednost". ${ }^{29}$ Ovaj stav podrazumeva uključenje u sistem za očuvanje i unapređenje nacionalnih bezbednosti država članica, kao što je primer OUN. Kolektivna bezbednost može se sagledati kroz tri načela međudržavnih odnosa, koja su od presudnog značaja za mir i bezbednost:

- države koje se formalno i neformalno udruže u sistem kolektivne bezbednosti odriču se upotrebe sile, kao sredstva za izmenu stanja status quo u međusobnim odnosi-

\footnotetext{
${ }^{27}$ Deutsch K., Political Community and Notrh Atlantic Area, Princenton University Press, Princenton, 1957. god., str. 5.

${ }^{28}$ Симић Д., „Савремене теорије безбедности“ у: Јанковић П., Реформа сектора безбедности - зборник предавања, Г17 институт, Београд, 2003. год., стр. 20-27.

${ }^{29}$ Димитријевић В., Појам безбедности у међународним односима, Савез удружења правника Југославије, Београд, 1973. год., стр. 53.
} 
ma, kao i da dosledno poštuju zahtev da sve svoje sporove i sukobe rešavaju miroljubivim sredstvima;

- sve države obuhvaćene sistemom kolektivne bezbednosti proširuju zamisao vlastite nacionalne bezbednosti i uzimaju kao vrednost interes međunarodnog društva u celini, što konkretno znači da, ako je jedna članica napadnuta, dužnost ostalih jeste da se zajednički suprotstave agresiji;

- razvijanje međusobnog poverenja i prevazilaženje straha u odnosima među državama, kako bi se sopstvena sudbina poverila ovoj usavršenoj ustanovi.

\section{Alternativno-kritički pristup}

Ova struja obuhvata savremena promišljanja o bezbednosti koja čine ideje: postmarksizma, feminizma, mirovnih studija i postmodernizma. Prvo što je važno naglasiti jeste da pripadnici ovog pravca, zapravo, sa jedne strane, zajednički dele stav o odbacivanju osnovnih ontoloških pretpostavki realizma i liberalnog institucionalizma, o pojmu anarhije, kao osnovne odlike međunarodnih odnosa i umesto države kao referentne objekte bezbednosti označavaju: društvene grupe i pojedince (kod postmarksista su to društvene klase), a sa duge strane su metodološki, konceptualno i epistemološki svaki za sebe posebni. Pri tome naglašavaju i ulogu nedržavnih subjekata, kao i nevojne vidove bezbednosti. Takođe, postavili su bitno drugačije poglede na promišljanje bezbednosti. ${ }^{30}$

Pripadnici socijalno-konstruktivističke teorije prihvataju stanovište da su zbog anarhičnog stanja međunarodnih odnosa države i dalje ključni i referentni objekti bezbednosti, jer postojeći međunarodni odnosi, kao i međusobne aktivnosti njihovih subjekata, neposredno određuju ponašanje država. Jedan od elemenata koji određuju međunarodne odnose čine društvene strukture zasnovane na zajedničkim idejama i predstavama o međunarodnoj bezbednosti, vladavini prava, međunarodnim institucijama i njihovim delatnostima. Njihovi postupci nisuodređeni anarhijom, nego načinom na koji države, društveno konstruišu i zatim reaguju na značenja koja pripisuju politici sile, tako da sa promenom njihove definicije može doći do evolucije prakse saradnje. ${ }^{31}$

Značajna je i feministička struja u čijoj osnovi je upozorenje da je zapostavljen interes i mišljenje žena u međunarodnoj politici. Postmodernistički pravac uveo je potpuni relativizam u odnosu na istinu i činjenice. Uvereni su da govor moći može biti zamenjen govorom zajedništva, što bi dovelo do mira, saradnje i sklada u odnosima između društva i država.

\section{Globalistički pogled na bezbednost}

„Kao posledica globalizma i posebno, zahvaljujući posledicama delovanja globalizacijskih „talasa“ u poslednjoj deceniji XX veka neki govore i o postojanju odnosa globalne zajednice koja u svoj sastav, pre svega, kao osnovne jedinice obuhvata pojedince, pa

\footnotetext{
${ }^{30}$ Симић Д., „Савремене теорије безбедности“ у:Јанковић П., Реформа сектора безбедности - зборник предавања, Г17 институт, Београд, 2003. год., стр. 27-35.

${ }^{31}$ Кегли Ч. И Виткоф Ј. Р., Светска политика-тренд и трансформација, Прометеј, Београд, 2004. год., стр. 105-112.
} 
tek onda i narode, različite biosocijalne zajednice, društvene grupe itd. Ima i onih koji smatraju da sistem suverenih država prerasta u svetsku zajednicu pojedinaca ponajvišem učinkom međunarodnog prava i međunarodnih organizacija koje je pridrža-vaju - novi subjekti, po njima, preobražavaju međunarodno pravo iz međudržavnog u pravo svetske zajednice (the Law of world community), transnacionalno pravo (Transnational law), zajedničko pravo čovečanstva (the common law of mankind) ili najšire, u svetsko pravo (world law)"."

Globalno društvo je proizvod globalizacije u svim njenim vidovima i kao takvo suočava se sa globalnim bezbedonosnim izazovima i pretnjama: nekontrolisanim neravnomernim rastom stanovništva, siromaštvom, terorizmom, širenjem oružja za masovno uništenje, organizovanim kriminalom, izvesnošću globalne ekološke zagađenosti, nestašicom pitke vode i zdrave hrane itd. Ovakvo stanje zahteva obavljanje bezbednosnih funkcija od strane nekakvog globalnog sistema bezbednosti, koji još nije izgrađen. Prema globalistima nacionalna država ne može odgovoriti na ove nove izazove. U tako izmenjenim uslovima međunarodni sistem ne ugrožavaju više pretnje međudržavnih sukoba već sukobi unutar pojedinih država, uzrokovani najčešće nacionalno-etničkim, ideoIoškim ili verskim suprotnostima. U okviru globalne zajednice osnovna jedinica je pojedinac, čija je bezbednost od ključnog značaja i iz koje proizilazi bezbednost bilo kog višeg nivoa: grupnog, nacionalnog, međunarodnog ili globalnog. Generalno, globalisti su mnogo doprineli postavljanju bezbednosti pojedinca u središte zamisli bezbednosti.

\section{Konceptualna analiza}

Da bi se krenulo ka određenju koncepta bezbednosti, kao pomoć može da posluži rad Boldvina pod nazivom „Koncept bezbednosti”, koji se zasniva na eseju „Nacionalna bezbednost" Arnolda Volfera, kao jednom nejasnom simbolu, a objavljen je pre četrdeset godina. lako mnogi misle da je Arnold napustio ovaj pojam kao besmislen ili beznadežno nejasan, ali jeste naglasio problem pojmovnog određenja, što se može zaključiti iz stava o potrebi dalje specifikacije ili određenja, kako bi se otklonila konfuzija koja je neprihvatljiva za političare ili naučnike. Ova specifikacija odnosi se na koncept nacionalne bezbednosti kao politički cilj, ali i kao sredstvo za njegovo postizanje. Predmet analize u ovom radu biće dalji razvoj ove specifikacije i dovođenje u kontekst novije literature.

Konceptualna analiza se ne odnosi na proveru hipoteza ili izgradnju teorija, iako ima veze sa oba predmeta. Feliks Openhajm ukazivao je na to da tumačenje jezika političkih nauka nije uzaludna semantička vežba, već na mnogo načina najefektivniji način rešavanja substantivnih problema istraživanja. ${ }^{33}$

Objašnjenje koncepta ima za cilj postavljanje kriterijuma koje je obuhvatio Openhajm:

1. koncept bi trebalo da bude operativan u širem smislu, iako ne bi trebalo da bude tumačen kao zahtev za kvantifikaciju,

\footnotetext{
${ }^{32}$ Симић Д., Поредак света, Завод за уџбенике и наставна средства, Београд, 1999. год., стр. 209-210.

${ }^{33}$ Felix E. Oppenheim, 'The Language of Political Inquiry: Problems of Clarification', in Fred I. Greenstein and Nelson W. Polsby (eds.), Handbook of Political Science, Vol. I: Political Science: Scope and Theory (Reading, MA, 1975), str. 284.
} 
2. koncept bi trebalo da ustanovi vezu definisanjem relevantnih termina;

3. poželjno je da koncept bude lako pregledan, tako što bi trebalo da privlači pažnju na teoretski važne aspekte predmetne materije;

4. koncept ne bi trebalo da isključuje empirijska istraživanja, pravljenjem definicija, koje bi trebalo empirijski istražiti;

5. koncept mora ostati blizak običnom jeziku, što ne znači da su termini definisani na način kako bi ih definisali svi ljudi, već da postavlja niz pravila koja se primenjuju u određenoj situaciji.

Potrebno je biti svestan ograničenja ovog pristupa, jer pojašnjavanje koncepta bezbednosti ne obezbeđuje empirijske propozicije, teorije ili analitičke okvire. lako je sam koncept koristan u njihovom konstruisanju nije zamena za njih.

Ovakav pristup je u suprotnosti sa onima koje imaju Bazan i Ulman. lako postavlja svoje viđenje kao istraživanja koncepta bezbednosti, njegova analiza povezuje konceptualnu analizu sa empirijskim posmatranjima. Buzan predstavlja verovatne argumente za empirijske propozicije da je sigurnost na individualnom nivou povezana sa sigurnošću na državnom i međunarodnom nivou. Njegovo insistiranje na tome da sigurnost ne može biti odvojena ni na jednom nivou stvara utisak da je to pre konceptualno nemoguće nego da nije najbolji istraživački postupak. Njegovo opravdanje za mešanje konceptualne i empirijske analize jeste da je istraživanje referentnih objekata u bezbednosti povezano sa istraživanjem neophodnih uslova. ${ }^{34}$

Međutim, shvatanje koncepta bezbednosti je fundamentalno drugačiji misaoni proces od određenja uslova pod kojima sigurnost može biti dostignuta. Konceptualno definisanje logično prethodi istraživanju neophodnih bezbednosnih uslova, zato što identifikacija takvih uslova pretpostavlja neki koncept bezbednosti. ${ }^{35}$

Neuspeh da prepozna logičke prioritete takođe se ogleda kod Ulmanovog stava da je jedan način o kretanju ka sveobuhvatnoj definiciji bezbednosti pitanje čega bi se neko odrekao da bi bio sigurniji. Takvo pitanje je besmisleno ako prethodno nije određen sam pojam sigurnosti. Ako neko nema koncept bezbednosti kako može znati da li je ugrožen njenim gubitkom. To je značajno za razmatranje cene, odnosno vrednosti bezbednosti, ali nije značajno za određenje samog pojma.

Da bi se izvršilo bliže pojmovno određenje potrebno je identifikovati određene specifikacije koje mogu da olakšaju analizu svrsishodnosti bezbednosne politike.

Za početak, bezbednost se može odrediti kao cilj politike i pristupiti daljem određenjem politike kao sredstva za dostizanje tog cilja.

Volfer karakteriše bezbednost kao „odsustvo pretnje usvojenim vrednostima”, što intuitivno predstavlja suštinu pojma bezbednosti. Kako postoji određena neodređenost fraze „odsustvo pretnje”, Boldvin je formuliše kao „mala mogućnost štete ostvarenim vrednostima”, ${ }^{36}$ što suštinski ne menja Volferovo značenje ali uključuje i takve pojave kao što su: zemljotresi, koje neki autori navode kao primer pretnje bezbednosti. Prednost ovakvog formulisanja može da se uoči na sledećem primeru: pri odgovoru na pretnju vojnog

\footnotetext{
${ }^{34}$ Buzan, People, States, pp. 20-1, 26. Italics added. See also, Barry Buzan, 'Peace, Power and Security: Contending Concepts in the Study of International Relations', Journal of Peace Research, 21 (1984), str. 25-109.

${ }^{35}$ Ullman, 'Redefining Security', str. 130, 133.

${ }^{36}$ David A. Boldvin, The concept of security, Review of International Studies (1997), 23, str. 13.
} 
napada države razvijaju politiku odvraćanja. Takva politika namenjena je da obezbedi bezbednost smanjujući verovatnoću da se desi napad. Kao odgovor na pretnju od zemljotresa, države razvijaju zakone i pravila izgradnje. To ne smanjuje verovatnoću da se desi zemljotres, ali smanjuje moguću štetu postojećih vrednosti. Time se postavlja težište na očuvanje postojećih vrednosti, a ne na prisustvo ili odsustvo pretnje. Na taj način bezbednost se, u najopštijem smislu, može definisati sa dve specifikacije (određenja): bezbednost za koga i bezbednost kojih vrednosti? ${ }^{37}$

\section{Bezbednost - za koga?}

Bazan je primetio besmislenost tvrdnje da koncept bezbednosti nema referentni objekat na koji se odnosi, budući da pojednostavljenje da se odnosi na pojedinca ili državu ne zadovoljava, jer postoji mnoštvo država i pojedinaca. Zbog toga traganje za referentnim objektom mora da ide zajedno sa određenjem neophodnih uslova. ${ }^{38}$ Međutim, kako je već uočeno, ovakav pristup pravi problem specifikacije koncepta sa empirijskim posmatranjem. Da bi se omogućila specifikacija koncepta potrebno je odgovoriti na pitanje - bezbednost za koga? Izbor zavisi od posebnih interesovanja onog ko istražuje i može biti za: pojedinca (nekog, većine ili svih), države (jedne, više ili svih), međunarodne zajednice (nekog, većine ili svih) itd.

\section{Bezbednost - kojih vrednosti?}

Pojedinci, države ili druge društvene organizacije mogu imati različite i mnoge vrednosti. To može uključiti: fizičku sigurnost, ekonomsko blagostanje, autonomiju, psihološko blagostanje itd. Koncept nacionalne bezbednosti tradicionalno uključuje političku nezavisnost, suverenitet i teritorijalni integritet. Pojedinci u to ubrajaju održavanje ekonomskih odnosa sa ostatkom sveta, pod razumnim uslovima. U slučaju da se omane sa specifikacijom vrednosti koje podrazumeva nacionalna bezbednost stvara se konfuzija.

Neki autori prave razliku između objektivne i subjektivne dimenzije bazbednosti. Time se ukazuje na problem precenjivanja ili potcenjivanja verovatnoće štete na vrednostima koje se štite. Ukoliko se precenjuje cilj politike bezbednosti, može biti smanjen neopravdani strah, dok u drugom slučaju to može biti osećaj lažne sigurnosti.

Bitno je shvatiti da specifikacija ove dimenzije bezbednosti nikako ne treba da bude proglašena kao vitalni interes ili ključna vrednost, jer to sigurno dovodi do predrasuda o vrednosti bezbednosti kao političkog cilja, što bezbednost može staviti ispred drugih političkih ciljeva.

lako su ove dve specifikacije, bezbednost za koga i bezbednost kojih vrednosti, dovoljne da definišu sam koncept bezbednosti, ipak nisu dovoljne da odgovore na to kako do nje doći. U nameri da se omogući poređenje različitih politika bezbednosti i koja politika obezbeđuje dostizanje drugih ciljeva, potrebno je razraditi naredne specifikacije.

\footnotetext{
${ }^{37}$ isto.

${ }^{38}$ isto.
} 


\section{Koliko mnogo bezbednosti?}

Neki autori ističu da je bezbednost vrednost koju nacije mogu da imaju više ili manje i da njena veličina može na neki način da se određuje. Brodi i Volfer su istovremeno primetili da neki ne vide bezbednost kao nešto čija veličina može da se meri. ${ }^{39} \mathrm{U}$ tom smislu postoji stav da bezbednost ne može da se vrednuje već se može konstatovati da je ima ili ne, odnosno možemo biti sigurni ili nesigurni, a ne delimično sigurni.

lako mnogi kritikuju ovakav pristup, ova ideja nije besmislena, jer sama reč implicira apsolutno stanje, jer nešto je ili sigurno ili nije. Ako je to istina, onda treba napustiti ideju o konceptu bezbednosti kao analitičkom konceptu. Međutim, to ne može da bude opravdano i u svakodnevnoj upotrebi možemo govoriti o različitim stepenima bezbednosti. To se može potkrepiti činjenicom da je, kao i svaka težnja za nečim apsolutnim, potreba države da dostigne apsolutnu bezbednost zapravo nedostižna. Ovu činjenicu neki autori (Bazan) koriste kao prilog tezi da je suštinski pojam bezbednosti neodređen koncept. Isti autori dalje naglašavaju da se, ukoliko se bezbednost može meriti, postavlja logično pitanje, na koje je nemoguće odgovoriti - koliko je bezbednosti dovoljno? To je slično pitanju koje ekonomisti postavliaju sebi - kako rasporediti resurse da bi se ostvarili najveći profiti?

Nasuprot njima postoji stanovište da je dostizanje ciljeva uvek stvar određenog stepena ili nivoa. U svetu u kojem razbacani resursi treba da se rasporede između suprotstavljenih ciljeva, nijedan od njih ne može biti potpuno dostignut i zbog toga niko ne treba da izbegava odgovor na pitanje - koliko je dovoljno?

\section{Od kojih pretnji?}

Oni koji koriste pojam bezbednosti obično imaju na umu određene vrste pretnji. Na primer, sistem bezbednosti kuća i drugih nepokretnosti usmeren je na provalnike, dok je sistem nacionalne bezbednosti usmeren na druge države. Budući da pretnje po dostignute vrednosti mogu doći iz mnogo izvora, korisno je da se ova dimenzija tačno specificira. Na primer, nejasno određenje „komunistička pretnja”, koju je percipirao NATO tokom hladnog rata, bio je promašaj, jer nije specifično upućivao na to da li je problem ideološka pretnja, ekonomska, vojna ili kombinacija, što je onemogućavalo razumnu raspravu o prirodi i veličini pretnje. Ovakav koncept pretnje razlikuje se od onog koji koriste studenti međunarodnih odnosa i bezbednosnih studija, gde se pretnja odnosi na akciju koja uslovno treba da se desi ako nečiji zahtevi nisu ispunjeni. Međutim, s tim u vezi, neki autori obrazlažu da se koncept bezbednosti može proširiti i na fenomene kao što su epidemije, poplave, zemljotresi ili suše. Zapravo, ne postoji razlog da se ne upotrebi ovako prošireni koncept pretnje.

\section{Cena ostvarivanja bezbednosti}

Ostvarenje i dostizanje bezbednosti uključuje troškove koji se moraju snositi i čime se uskraćuju drugi ciljevi. Specifikacija ove dimenzije politike bezbednosti je važna, jer postoje autori koji smatraju da bezbednost nema cenu. Često se u ovakvim tvrdnjama polazi od toga da je nacionalna bezbednost ključna vrednost i opisuje se kao interes koji se ostvaruje bez obzira na cenu.

\footnotetext{
${ }^{39}$ Bernard Brodie, National Security Policy and Economic Stability, Yale Institute for International Studies Memorandum No. 33 (New Haven, CT, 1950), str. 5.
} 
Međutim, sa stanovišta racionalnih političara ne postoje takvi interesi. Cena je uvek bitna. Ne postoji potreba za sukobom između željenih ciljeva kao što je velika i snažna oružana snaga, nezavisnost od snabdevanja naftom iz jednih izvora, samoodrživosti razvoja siromašnih zemalja ili zdravog okruženja na primer. Svi ovi ciljevi mogu biti dostignuti ako postoji želja naroda da pravilno raspodeli resurse.

U razmišljanju o bezbednosti, kao i drugim ciljevima politike uvek treba imati na umu da sve ima svoju cenu!

\section{Period ostvarivanja politike bezbednosti}

Najracionalnija politika bezbednosti na duže staze može bitno da se razlikuje od one za kraći period. Kratkoročno „visoka ograda, zastrašujući pas čuvar i veliko oružje” mogu biti korisni da se zaštitite od suseda. Međutim, dugoročno je pametnije da se sprijateljite sa njim. To su dva pola rešavanja bezbednosnog problema, koji su prisutni na svim poljima - od bezbednosti sopstvenog doma do međunarodne bezbednosti. Očigledan je primer Izraela, koji poslednjih šezdeset godina vodi oružane sukobe sa arapskim okruženjem i često izlazi kao vojni pobednik, ali problem ostaje.

\section{Dimenzije bezbednosti}

Kao odgovor na Volferovu tvrdnju da su specifikacije potrebne da bi nacionalna bezbednost zvučala kao koristan savet ili za naučnu upotrebu, neko bi mogao da izvrši specifikaciju bezbednosti u odnosu na subjekte čija vrednost treba da bude bezbedna, zatim koje se vrednosti razmatraju, stepen bezbednosti, vrste pretnji, sredstva za suzbijanje tih pretnji, njihova cena i relevantan period.

Međutim, ostaje pitanje: koliko je specifikacija potrebno? Moraju li sve dimenzije da budu detaljno razrađene svaki put kada neko koristi koncept bezbednosti. Naravno, odgovor je negativan, jer broj dimenzija i nivo detaljnosti zavisi od opsega istraživanja. Svaka dimenzija može biti šire ili uže istražena i ne mora svaka uvek da bude predmet istraživanja. U većini slučajeva ipak postoji razumna osnova da neke indikacije o tome koliko je bezbednosti potrebno za koje vrednosti i koje subjekte u odnosu na pretnje. Radi sistemskog poređenja političkih alternativa moraju da se odrede najmanje tri specifikacije: sredstva, troškovi i vremenski period.

lako dimenzije bezbednosti mogu biti određene vrlo široko, svrsishodnost koncepta ne raste sa njihovim širenjem. Kao primer za tu tvrdnju može poslužiti sledeće: ako određena pretnja ugrožava sve dostignute vrednosti države takva vrednost postaje sinonim za blagostanje ili nacionalni interes i onda je praktično neupotrebljiva za razdvajanje političkih ciljeva.

\section{Novi koncept bezbednosti}

Sadržaj pojma bezbednosti proširio se u svim pravcima izvan nacionalne države, nagore međunarodne institucije, nadole - prema lokalnim i regionalnim vladama i horizontalno - prema nevladinim organizacijama, medijima, javnom mnjenju i tržištu. Zavisno od obuhvata predmeta na koji se pojam bezbednosti odnosi, razlikuju se: globalna bezbednost, međunarodna, regionalna, državna, nacionalna, društvena, ljudska bezbednost ( u čijem središtu je čovek

\footnotetext{
${ }^{40}$ David A. Baldwin, The concept of security, Review of International Studies (1997), 23, str. 18.
} 
pojedinac), kolektivna (koncept bezbednosti zemalja članica OUN), zajednička bezbednost (u okviru EU i ZND) i kooperativna bezbednost (koncept bezbednosti članica NATO-a).

Bezbednost u najširem, političko-pravnom smislu obuhvata: mere, aktivnosti čuvanja i zaštite od ugrožavanja nezavisnosti, integriteta jedne zemlje (države, nacije) i unutrašnjeg ustavnog i pravnog poretka. ${ }^{41} \mathrm{U}$ prvom slučaju radi se o spolinioj, a u drugom o unutrašnjoi bezbednosti, pri čemu se prema objektu zaštite razlikuju: opšta (javna), državna, lična, kolektivna i imovinska bezbednost. Opšta (javna) bezbednost podrazumeva zaštitu ličnih, imovinskih, političkih i drugih prava i sloboda građana od kriminalnog uskraćivanja njihovog korišćenja. Lična prava i slobode obuhvataju zaštitu života, neprikosnovenost i integriteta ličnosti, zatim nepovredivost stana, tajnost pisma, sredstva veze, slobodu kretanja i nastanjivanja, kao i drugih ličnih i političkih prava. Pod zaštitom imovinskih prava označava se obezbeđenje postojećih imovinsko-pravnih odnosa, zaštita objekata od krađe, razbojništva i svakog drugog oblika narušavanja imovinskih prava pojedinca. Državna bezbednost obuhvata prevenciju protiv krivičnih dela kojima se ugrožava država, odnosno političkih krivičnih dela, otkrivanje organizovanja ovih dela i sprečavanje, predupređivanje njihovog izvršenja, zatim otkrivanje sprovedenih dela ove prirode i hvatanje, gonjenje njihovih izvršilaca, odnosno organizatora. Tu se uključuju sve vrste mera, postupaka i aktivnosti usmerenih ka realizaciji postavljenih ciljeva.

Završetkom hladnog rata tradicionalni „relnopolitički” koncept bezbednosti, koji počiva na mađunarodnom sistemu država, proizašlom vestfalskim mirom 1647. godine, pokazao je svoju nedelotvornost, čak i u domenu nacionalne bezbednosti. Sistem država je ozbiljno uzdrman velikim promenama u međunarodnim odnosima i posledicama globalizacije, pri čemu postoje dva uopštena mišljenja, prema kojima je država, sa jedne strane, i dalje glavni subjekat i objekat bezbednosti u svim njenim strukturama, dok je, sa druge strane, u uslovima globalizacije, osnovni generator krize i uzrok nesigurnosti građana, odnosno deo problema međunarodnog sistema. Procesi modernizacije uslovili su preoblikovanje međunarodnog sistema država, što je uslovilo pragmatičan nastup u preoblikovanju struktura, pri čemu je sistem država ipak ostao kao nezamenliiv princip u formiranju odnosa u međunarodnoi zajednici i svetskoj politici. Sve navedeno nalaže da se pri razmatranju sadržaja pojma bezbednosti analizira povezanost tog fenomena sa poimovima vrednosti potreba i interesa.

Dovodeći u međusobnu vezu pojmove bezbednosti i vrednosti, potrebno je ustanoviti u kojem obimu bezbednost označava istinsku vrednost društva i čoveka, imajući u vidu opšti sadržaj pojma vrednosti.

Ako shvatamo vrednosti kao bitne elemente društvene svesti unutar željenih i uspostavljenih kodeksa ponašanja, bezbednost kao autohton društveni koncept i integrativni deo sadržaja pojma slobode i prava građana predstavlja jednu od temeljnih vrednosti čoveka, društva i čitave ljudske civilizacije. Sa političkog stanovišta bezbednost je uslov za opstanak života, kako pojedinačnog, tako i društvenog. Na osnovu navedenog, bezbednost kao vrednost ukazuje na postojanje društveno-istorijski formulisanog načina ponašanja ljudi, zasnovanog na potrebi da se dostigne stepen bezbednosti koji podrazumeva odsustvo pretnje i postojanje mehanizama koji ih mogu zaštititi od pretnji koje ug-rožavaju njihov opstanak i egzistenciju pojedinih grupa, društva, države, međunarodnog okruženja i globalne zajednice. ${ }^{42}$

Potrebe predstavljaju određen nedostatak koji se nadoknađuje nekom konkretnom akcijom. Čovek primarno mora da zadovolji svoje osnovne fiziološke potrebe, a nakon toga slede potrebe za bezbednošću. Zadovoljavanje bezbednosnih potreba predstavlja i

\footnotetext{
${ }^{41}$ Политичка енциклопедија, Савремена администрација, Београд, 1975. год., стр. 79.

${ }^{42}$ Слободан Нешковић, Безбедност и реформе у Србији, Прометеј, Београд, 2006. год. стр. 11-17.
} 
njihovu razvojnost i osavremenjavanje u skladu sa demokratskim procesima društva i prisutnim protivrečnostima u zaštiti garantovanih prava i sloboda građana. Bezbednost predstavlja uslovnost mogućnosti dostizanja, očuvanja i unapređenja nivoa ljudskog blagostanja, koji čini slobodan i svestran razvoj pojedinca i društva. Čovek teži i zadovoljenju ostalih potreba u koje spadaju nauka, sport, umetnost i dr., ali je bezbednost suštinski, fundamentalni uslov za ostvarenje sloboda i prava građana.

Pojam interesa izražava objektivne i subjektivne strane konkretnih društvenih uslova u kojima deluju pojedinci i određene društvene grupe. ${ }^{43}$ Kao i u slučaju vrednosti i potreba, interes određuje sadržaj poima bezbednosti. Bezbednost kao interes predstavlia svesno, racionalno delovanje pojedinca za sopstveni fizički opstanak, ali i druge dimenzije njegove društvenosti, postojania i delania. Određivanje bezbednosti, kao suštinskog interesa pojedinca i širih društvenih zajednica, određuje širenje tog interesa od pojedinačnog ka opštem. Tako je u društveno-političkoi teoriii uobličen tradicionalni koncept (nacionalna i međunarodna bezbednost), a u novije vreme: pojedinačna, društvena i globalna bezbednost, što znači da je prošireno istraživačko polje bezbednosti, odnosno sam sadržaj pojma bezbednosti.

Shvatanjem bezbednosti, kao istinske ljudske vrednosti, potrebe i interesa, dolazimo do slobode kao najuzvišenijeg ideala i univerzalne vrednosti svestranog razvoja čoveka. Tako shvaćena sloboda, još od vremena antičke Grčke, podrazumeva političko pravo građana da odlučuje o svim javnim pitanjima, a samim tim i o pitanjima iz oblasti bezbednosti.

Utvrđivanje punog sadržaja pojma bezbednosti u savremenom međunarodnom ambijentu zahteva znatno širi, oštriji i radikalniji pristup, što se u okviru modernih studija bezbednosti krajem XX i početkom XXI veka svodi na sledeće osnovne forme:

- koncept bezbednosti je proširen od nacionalne bezbednosti na bezbednost pojedinca i grupa, što predstavlja pomeranje od nacija prema pojedincima, odnosno isticanje značaja pojedinaca i grupa kao referentnih objekata bezbednosti;

- proširenje od nacionalne bezbednosti ka bezbednosti međunarodnog sistema (međunarodna bezbednost) ili nadnacionalnom fizičkom okruženju - širenje nagore, od nacije prema biosferi. Ovo širenje obuhvata utvrđivanje onih referentnih objekata bezbednosti za koje bezbednost mora biti garantovana;

- koncept bezbednosti se širi horizontalno, što predstavlja klasifikaciju po tipovima bezbednosti. Koncept se širi od voine prema političkoj, ekonomskoj i bezbednosti životne sredine i

- politička odgovornost za „obezbeđenje bezbednosti”, odnosno obuhvatanjem svih pomenutih koncepata bezbednosti samostalno se proširila.

\section{Zaključak}

Uprkos tome što je tokom poslednjih pedeset godina učestala upotreba termina bezbednost nedovoljno pažnje posvećeno je objašnjenju samog koncepta. lako je koncept moći generisao pravo mnoštvo literature, slična literatura iz oblasti bezbednosti je prilično oskudna. Neki stručnjaci tvrde da je, u skladu sa suštinski problematičnim značenjem pojma bezbednosti, verovatno tačnije opisati koncept bezbednosti kao nedovoljno objašnjen nego kao problematičan. Svrha ovog rada je pokušaj objašnjavanja koncepta bezbednosti u širem kontekstu, kako bi bio primenljiv na više nivoa, ali sa posebnim osvrtom na nacionalnu bezbednost. Takođe, bezbednost je definisana kao politički cilj, dovoljno jasan da se razlikuje od drugih ciljeva. Budući da se bezbednost bori za ograničene resurse, nužno je da se razlikuje od ostalih ciljeva, ali mora da

\footnotetext{
${ }^{43}$ Исто.
} 
ima mogućnost komparacije sa njima. To zahteva da relativan značaj bezbednosti bude radije otvoren nego da se stvara koncept upotrebom termina kao što su: vitalni interesi ili ključne vrednosti. Kako je već pomenuto, postoji potreba za određenjima (specifikacijama), kako bi se načinio koncept bezbednosti, dovoljno upotrebljiv za političko savetovanje ili naučnu raspravu. Posebno je značajna važnost ponavljanja i pojašnjavanja specifikacija, budući da živimo u vreme preovladavanja zakona tržišta, gde se vodi stalna debata o preraspodeli resursa između bezbednosti i drugih političkih ciljeva, a važnije je nego ikad da se omogući komparacija vrednosti bezbednosti sa drugim ciljevima. Kao što je rečeno, Openhajmov kriterijum za evaluaciju naučnih koncepata može biti primenljiv i na koncept bezbednosti.

\section{Literatura}

[1] American Political Science Association, 14 September 1994.

[2] Arnold Wolfers, "National Security" as an Ambiguous Symbol, Political Science Quarterly, 67 (1952).

[3] Bernard Brodie, National Security Policy and Economic Stability, Yale Institute for International Studies Memorandum No. 33 (New Haven, CT, 1950).

[4] Buzan B., People State and Fear: An Agenda for International Security Studies/ In the Post Cold War Era, Pearson Longman, London, 1991.

[5] Contending Concepts in the Study of International Relations', Journal of Peace Research, 21 (1984).

[6] David A. Baldwin, The concept of security, Review of International Studies ( 1997).

[7] David A. Baldwin, The concept of security, Review of International Studies ( 1997) 23.

[8] Felix E. Oppenheim, 'The Language of Political Inquiry: Problems of Clarification', in Fred I. Greenstein and Nelson W. Polsby (eds.), Handbook of Political Science, Vol. I: Political Science: Scope and Theory (Reading, MA, 1975).

[9] Griyol A., Realities of American Foreign Policy, Njujork, 1960.

[10] Hewedy A., Militarisation and Security in the Middle East, Pinter Publishers, London.

[11] Klaus Knorr, 'National Security Studies: Scope and Structure of the Field', in Frank N. Trager and PhilipS. Kronenberg (eds.), National Security and American Society: Theory, Process and Policy (Lawrence, KS, 1973).

[12] Peter Digeser, 'The Concept of Security', paper delivered at the 1994 Annual Meeting of the American Political Science Association, 14 September 1994.

[13] Richard H. Ullman, 'Redefining Security', International Security, 8 (1983).

[14] Richard Smoke, 'National Security Affairs', in Fred I. Greenstein and Nelson W Polsby (eds.), Handbook of Political Science, Vol. 8: International Politics (Reading, MA, 1975).

[15] Sidel V. Levy B., Security and Public health.in, Social Justice Vol 29.

[16] W B. Gallie, 'Essentially Contested Concepts', Proceedings of the Aristotelian Society, N.S., 56 (1956).

[17] Кенеди П., Припрема за ХХИ век, Службени лист, Београд, 1997.

[18] Кенет Волц, Тхеору оф Интернатионал Политицс (Реадинг, МА, 1979), анд 'Тхе Емергинг Струцтуре оф Интернатионал Политицс', Интернатионал Сецуриту, 18 (1993).

[19] Ковачевић С., Основи система ДСЗ, ВШУП Београд, 1980.

[20] Милетић А., Национални интерес у америчкој територији међународних односа, Савремена аминистрација, Београд, 1978.

[21] Аврамов С., Безбедност у 21. Веку, Зборник радова СИМБОН 200, Београд.

[22] Слободан Нешковић, Безбедност и реформе у Србији, Прометеј, Београд, 2006. 